\title{
On the Rupture of Cholesterol Oxide. II $^{1)}$
}

\author{
by \\ Jungo HatTori \\ [From the Scientific Laboratory of Ch. Takeda \& Co. Ltd., Osaka.]
}

(Received, May 2 nd. 1940.)

According to the technique of Ruzicka ${ }^{2}$ ), the author obtained a substance Fp 198-200', in addition to 3-acetoxy-5 hydroxy-6-chlor-cholestane (I) $\mathrm{Fp} 190-191^{\circ}$, by the reaction of dry $\mathrm{HCl}$ gas on $\beta$-cholesterol-acetate oxide (Fp 114-115 $\left.,[\alpha]_{1}:-22.5\right)$. When this compound is acetylated by the usual method, it gave 3,6-diacetoxy-5-chlor-cholestane 3 ). This shows that the compound is 3 -acetoxy-5-chlor-6-hydroxycholestane (II). If $a$ cholesterol-acetate oxide $\left(\mathrm{Fp} 99^{\circ},[\alpha]_{\mathrm{D}}:-42.5^{\circ}\right)$ is treated with dry $\mathrm{HCl}$ gas in the same manner, compound (I) alone is formed. In order to study the reason why two kinds of chlor-compound are formed from $\beta$-oxide, the author prepared $\beta$-oxide from cholestanetriol according to Windaus ${ }^{4}$ ).

3,6-Diacetoxy-5-hydroxycholestane (Fp 167.5-168.5 ) was saponified by alcoholic $\mathrm{KOH}$ to obtain cholestanetriol. The latter was treated with $\mathrm{HCl}$-methanol, and then

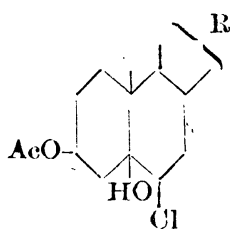

( I )

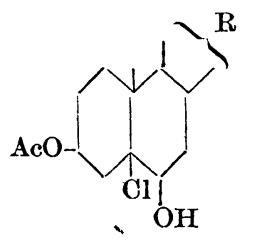

(II)

acetylated to obtain 3,6-diacetoxy-5-chlorcholestane. The point which should be emphasized in this reaction is the fact that the compound (I) is obtained as a byproduct. The reason for this has not as yet been studied.

The above chlorhydrine was repeatedly recrystallized from alcohol to obtain a

1) The first paper: this Journal 59, $129[1939$ ?.

2) Helv. Chim. Acta 20, 809 [19:37].

3) Ber. 70, 1947 [1937].

4) Z. physiol. Chem. 117, 146 [1922] , 
substance melting at $112-113^{\circ},[\alpha]_{\mathrm{v}}:-45.0^{\circ}$. By treating this compound with $10 \%$ alcoholic $\mathrm{KOH}, \beta$-cholesterol oxide, needles, Fp $136^{\circ}$ (not sharp), $[\alpha]_{\mathrm{b}}$ : $-10.4^{\circ}$ was obtained. By the usual method of acetylation, it gave the acetate, Fp 112-113 ${ }^{\circ},[a]_{\mathrm{D}}$ : $\pm \mathrm{O}^{\circ}$. By assuming that this is a pure $\beta$-oxide, the rupture of the oxide-ring was investigated.

When the above $\beta$-cholesterol-acetate oxide was treated with dry $\mathrm{HCl}$ gas, the compound (II) was obtained in almost quantitative yreld, but no formation of compound (I) was observed. When the acetate oxide was ruptured with glacial acetic acid, 3,5diacetoxy-6-hydroxycholestane was obtained.

In the light of these facts, it became clear that the claim that Ruzicka made of having obtained the compound (I) from $\beta$-oxide, or that the reason the present author obtained 3,6-diacetoxy-5-hydroxycholestane from the same compound was found to be due to the presence of $\alpha$-oxide, mixed with the raw material, $\beta$-oxide.

Judging from the examination of the $\mathrm{X}$-ray pictures of the powder, the substance spoken of as $\beta$-oxide is not a simple mixture of $\alpha$-oxide and $\beta$-oxide, but appears to be a molecular compound of the two substances.

\title{
On the Chromic Acid Oxidation of Typha-Sterol.
}

\author{
by \\ Jungo HatTori and Katutaro NaKamura - \\ [From the Scientific Laboratory of Ch. Takeda and Co. Ltd., Osaka.] \\ (Received, May 2 nd. 1940.)
}

When the acetate (Fp 125-126 $)$ of the sterol of typha was brominated, a dibromide, $\mathrm{Zp} 124-125^{\circ}$ was obtained. This compound was oxidized with $\mathrm{CrO}_{3}$ in glacial acetic acid, and trans-dehydroandrosteron was isolated from the neutral oxidation products. From the acidic fraction of the oxidation products, a substance, platelets, Fp $249^{\circ}$ (with decomposition) was isolated. The Fp of this substance corresponds roughly to 


\title{
コレステリン·オキシドの開裂に就て (第 II 報) ${ }^{1)}$
}

\author{
服部順五. \\ 株式會社武田長兵衞商店研究部（昭和 15 年 5 月 2 日受理）
}

著者は嘗て 3-Oxy-cholansäure-5,6-oxyd の研究 $\left.{ }^{2}\right)$ に當り一つの疑問に逢着した。郎ち Cholesterin の場合には圖示したやうに $\alpha$-Cholesterin-oxyd (I) から Triol (II) 及び Chlorhydrin（III）を經て $\beta$-Cholesterin-oxyd (IV) が生成すると報告されて居るが, $a-3-O x y-$ cholansäure-5,6-oxyd 飞就て同樣の反應を行つた場合には依然として $\alpha$-Oxyd が復生し, $\beta$ Oxyd への轉位は認められなかつた。一方 Ruzicka 等3) は $\beta$-Cholesterin-acetat-oxyd に乾燥 監酸瓦斯を作用させを場合 3-Acetoxy-5-oxy-6-chlor-cholestan (V) が生成する事を報告して 居る.著者は同氏等の實驗を追試した結果上述の疑問を解決し得をと同時に 2 3 の新事實を 見出したので其等に就て此處に報告する。

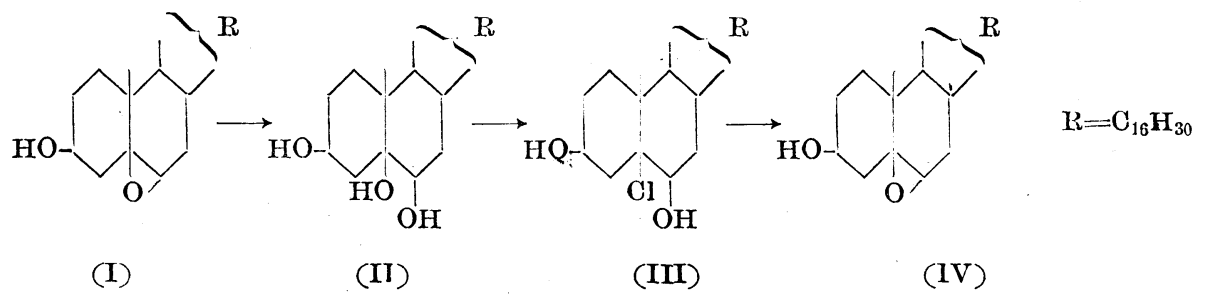

先づ $\beta$-Cholesterin-acetat-oxyd ( Fp 114 1150) どクロロホルム中で乾燥監酸瓦斯を作用さ せた後アルコールから再結晶して細針狀晶（Fp 190～191º）を得を。本品は無水醋酸で醋化さ れない故, Ruzicka 等の記載した 3-Acetoxy-5-oxy-6-chlor-cholestan (V) である事が分る.

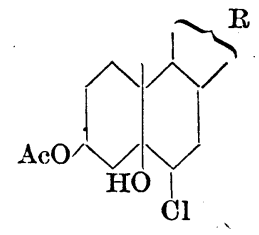

(V)

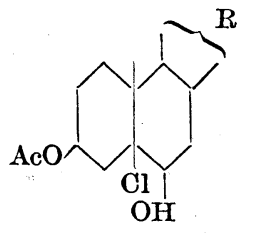

(VI)

次に（V) を滤別したアルコール母液から現れ る結晶を醋酸エステルで再結晶して薄い板狀晶 (Fp 198〜200) を得を. 本品と（V）とを混 融すれば顯著な融點降下を起し，元素分析值は 兩者共 $\mathrm{C}_{29} \mathrm{H}_{49} \mathrm{O}_{3} \mathrm{Cl}$ 亿一致する. 從つて兩者は 瓦に異性體をなすものと推定される。本品をア 七チル化すると既知の 3,6-Diacetoxy-5-chlor-cholestan ((III) の Diacetat, Fp 112 113 $\left.{ }^{\circ}\right)^{4}$ )
1) 第 I 報, 本誌 59, 411 〔昭 14〕.
2) 本誌 59, 32 〔昭 14〕.
3) Helv. Chim. Acta 20, 809 [1937].
4) Ber. 70, 1947 (1937). 
が生成する。此の事實から本物質が 3-Acetoxy-5-chlor-6-oxy-cholestan（VI）である事を知 る. 之に反して $a$-Cholesterin-acetat-oxyd を同樣に乾燥鹽酸瓦斯で處理した場合には, 細針

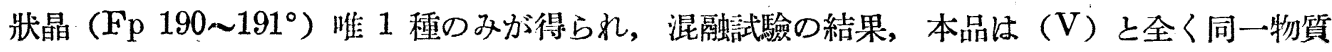
である事が分つた.5)

如斯 $\beta$-Oxyd 飞乾燥鹽酸瓦斯を作用させを場合 2 種のクロル化合體が生成する理由として, オキシド環の開裂に際し，(V) $\rightleftarrows(\mathrm{VI})$ の反應が行はれる事も一應考人られるが，實驗の部 に記与如く此の反應は事實行はれて居ない事が分明した。從つて原料に用ひた $\beta$-Oxyd を吟味 する必要を生じたので，著者注冒顗に記した如くCholestan-triol (II) から純料な $\beta$-Oxyd を 製して此の點を究明した.

Petrow.の記載に從つて製した 3,6-Diacetoxy-5-oxy-cholestan (Fp 167.5〜168.5 ) をアル コール性苛性カリで鹼化して得た Triol (II) 亿鹽酸瓦斯ーメタノールを作用させた後アセチル 化して文獻記載の 3,6-Diacetoxy-5-chlor-cholestan（(III）の Diacetat）を得た。茲に注意 す可き事は，此の際針狀晶（Fp 190１91） が副生する事であつて，混融試驗の結果本品は (V) ス一致する.（此のやう、 Triol から 2 種のクロル化合體が生成する原因が原料の不純 性に歸せられる可きか否かは未だ確めて居ない).6)

上述の 3,6-Diacetoxy-5-chlor-cholestan を立分と精製して Fp 112 113 ， [a $]_{\mathrm{D}}=-45.0^{\circ}$ の純度のものとなし，之を $10 \%$ アルコール性苛性カリで處理して $\beta$-Cholesterin-oxyd の針 狀晶 $\left(\mathrm{Fp} 136^{\circ}\right.$ (不銳敏)， $[\alpha]_{\mathrm{D}}=+10.4^{\circ}$ ) 在得た。李品と $\alpha$-Cholesterin-oxyd (Fp 141.5 $142^{\circ}$ ）とを混融すれば顯著な融點降下を起す。常法に從つて無水醋酸でアとチル化すれば，板

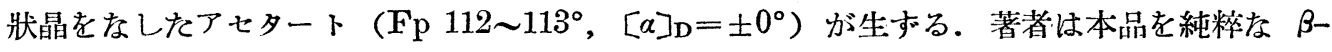
Oxyd と見倣して,オキシド環の開裂を檢した.

本品をクロロホルムに溶解し乾燥監酸瓦斯を作用させを所, 殆んど定量的に 3-Acetoxy-5chlor-6-oxy-cholestan（VI）を生じ，前飞述べた如き３-Acetoxy-5-oxy-6-chlor-cholestan (V)の副生は認められな汃つた。次に本品を水醋酸で開裂して得られる油狀物質をア七チル化 して既知の 3,5,6-Triacetoxy-cholestan の針狀晶（Fp 148.5 150 $)^{1}$ ) を得を．從つて中間體 として 3,5-Diacetoxy-6-oxy-cholestan が生成して居る事は容易に首肯し得る．之等の事實を 參照すれば Ruzicka 等ぶ $\beta$-Cholesterin-acetat-oxyd から (V) を得をと報告し又著者が前報1)

5),6）（前報告（本誌 59,32〔昭 14】）に於て著者は Cholesterin の場合から類推して 3,6-Diacetoxy5-oxy-cholansäuremethylester 及び $\alpha-3-0 x y$-cholansäuremethylester-5.6-oxyd $か ら \mathrm{HCl}+\mathrm{CH}_{3} \mathrm{OH}$ の 作用によつて 3,6-Dioxy-5-chlor-cholansäuremethylester が生成すると記したが, 之等の成績から本品が 實は 3,5-Dioxy-6-chlor-cholansäuremethylester であつた事が分る. 從つて本品がモノアセタート，モノべ

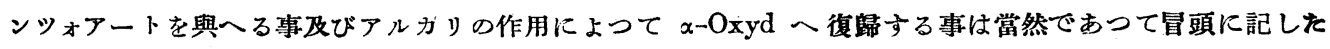
疑問も立に水解する). 
K於て同物質から 3,6-Diacetoxy-5-oxy-cholestan を得た如く考人たのは，何れも其の原料と して用ひた $\beta$-Oxyd の中に $\alpha$-Oxyd が混在して居た事に原因して居たと思惟される.

然し，茲に原料に用ひた $\beta$-Cholesterin-acetat-oxyd (a) $\left([\alpha]_{D}=-22.5^{\circ}\right)$ と, Chlorhydrin から製した $\beta$-Cholesterin-acetat-oxyd (b) $\left([\alpha]_{D}= \pm 0^{\circ}\right)$ 及び $\alpha$-Cholesterin-acetat-oxyd (c) $\left([a]_{\mathrm{D}}=-42.5^{\circ}\right)$ とを比較して見ると，其等の旋光度から見て（a）の中にはほは牛量に近い （c）が混在して居ると考入ねばならない，果してさうだとすれば（b) が此のやうに多量の (c) を混じて居るにも關らず再結晶を繰り返しても融點は變化せず, 且つ 114〜115゚で銳敏に熔 融する事は奇異に感ぜられる。著者は此の點を明にするため, 之等 3 者の X 線粉未寫真を撮 影した. 末尾に附した圖の中で第 1 圖は（a)，第 2 圖は（b)，第 3 圖は (c) の $\mathrm{X}$ 線粉末 寫貞である．之等を見れば明瞭に 3 者の相違が認められ，件も（a）の像は期待に反して (b) 及び（c）の像を重ねたものと一致しない，從つて上述した如く（a）が（b）と（c）との單なる 混合物とは考入られす寧ろ分子化合體の如きものを造つて居るのではなかららかと推察される. 試みに（b）と（c）との等量を熱メタノールに溶解後放冷して析出する結晶（d）（Fp 113〜 $114^{\circ}$ ) の X 線粉末寫眞（第 4 圖）“を撮影した所，(a)の像と全く一致する事を知つた. 之等 の結果だけから斷言するのは早計であるが，文獻上に記載された所謂 $\beta-O x y d$ なるものは $\alpha-$ Oxyd と純粹な $\beta-O x y d$ とから構成された一種の分子化合體であららと思はれる。

佾次に圖示する如く，本報及び前報〉に於て $\alpha$-及び $\beta-O x y d$ を同一條件のもとに開裂し て得を成績を比較對照する時, 之等オキシド環の開裂に際し, 其の立體配位を異にするに從ひ 一定の法則のもとに Radikal の導入が行はれる事實は興味深き事と考へられる.

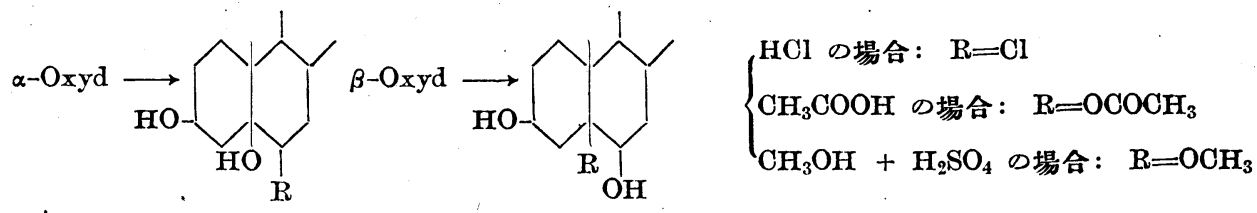

本研究に當り御愁篤な御㜞示を辱くした恩師朝比奈泰彥先生, 御指導と本稿の御校閱を賜つ た桑田智博士に謹謝し，元素分析を施行せられた笠原榮三, 今井晃久兩氏站に施光度測定及び $\mathbf{X}$ 線粉未寫䓂の撮影を實施せられを神尾英雄氏に深謝する。

實 驗 之 部

（本嗐告中に記載する融點は總て補正值である）

本實驗に供した試料は既に前報りに記したもので次の熔融點及び旋光度を示す。

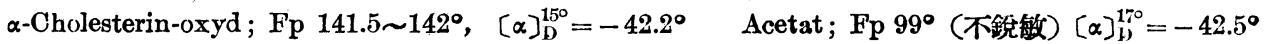

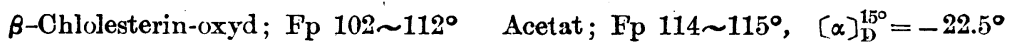




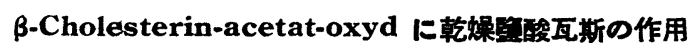

A) 3-Acetoxy-5-oxy-6-chlor-cholestan (V) の生成 $\quad \beta$-Cholesterin-acetat-oxyd $1 \mathrm{~g}$ をロロホ ルム $30 \mathrm{cc}$ に溶解し, 水冷しつつ乾燥而酸瓦斯を 1.5 時間導入後 1 夜放置する. 然る後減屒下にクロロホ ルムさ溜去し, 残渣をエーテルに溶解し稀 $\mathrm{NaOH}$ 溶液, 水で洗策, 乾燥後エーテルを溜去し, 残渣にアル コールを加へると針狀晶（約 $170^{\circ}$ で不銳敏に熔融する）が析出する. 之をアルコールから反覆再結晶して Fp 190〜191の細針狀晶を得た. Liebermann 反應は桃 $\rightarrow$ 紫 $\rightarrow$ 靑 $\rightarrow$ 綠色に移行する. 本品を無水醋酸と 1 時間煮沸したが原料を四收したのみでつた。

試料 (90 100 6 時間禹空乾燥) $3.330 \mathrm{mg}: \mathrm{CO}_{2} 8.830 \mathrm{mg}, \mathrm{H}_{2} \mathrm{O} 3.140 \mathrm{mg}$ - 試料 $4.045 \mathrm{mg}: \mathrm{AgCl}$ $1.260 \mathrm{mg}$.

$$
\begin{array}{llllllll}
\mathrm{C}_{29} \mathrm{H}_{49} \mathrm{O}_{3} \mathrm{Cl} & \text { 計算値 } & \mathrm{C} & 72.37, & \mathrm{H} & 10.27, & \mathrm{Cl} & 7.37 . \\
& \text { 實驗傎 } & \text { C } & 72.32, & \text { H } & 10.55, & \text { Cl } & 7.71 .
\end{array}
$$

B） 3-Acetoxy-5-chlor-6-oxy-cholestan (VI) の分離＼cjkstart前記（V) を分離したアルコール母液を 再びエーテルに溶解し，水洗，乾燥後エーテルを溜去し，残渣を醋酸エステルから反覆再結晶して Fp 198〜 $200^{\circ}$ の薄い板狀晶を得た，本品け顯著なクロールの熖色反應を現し，Liebermann 反應は呈色しない，本

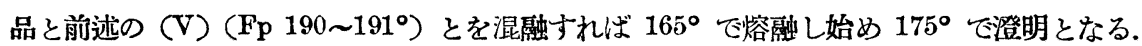

試料 $\left(100^{\circ}, 6\right.$ 時間傎空乾燥) $4.225 \mathrm{mg}$ : $\mathrm{CO}_{2} 11.280 \mathrm{mg}, \mathrm{H}_{2} \mathrm{O} 3.855 \mathrm{mg}$ — 試料 $4.440 \mathrm{mg}$ : $\mathrm{AgCl}$ $1.405 \mathrm{mg}$.

$$
\begin{array}{llllllll}
\left.\mathrm{C}_{29} \mathrm{H}_{49} \mathrm{O}_{3} \mathrm{Cl}\right] & \text { 計算值 } & \mathrm{C} & 72.37, & \mathrm{H} & 10.27, & \mathrm{Cl} & 7.37 . \\
& \text { 賽驗値 } & \mathrm{C} & 72.81, & \mathrm{H} & 10.21, & \mathrm{Cl} & 7.83 .
\end{array}
$$

アセチル化； 本品を無水醋酸と煮沸後常法に從つて處理した後アルコールから再結晶して Fp 112〜 $113^{\circ}$ の針狀晶を得た. 本品とCholestan-triol から製した 3.6-Diacetoxy-5-chlor-cholestan $\left.\left(F p 112 〜 113^{\circ}\right)^{4}\right)$ とを混融しても愿點下降下起らない.

a-Cholesterin-acetat-oxyd に乾燥路酸瓦斯の作用 $\quad \beta$-Cholesterin-acetat-oxyd に乾燥監酸瓦斯を 作用させた場合の A)の部に記述した如く處理して得たエーテル蒸溜残渣にアルコールを加へると Fp $188^{\circ}$ の針狀晶が析出する.之をアルコールから 1 包再結晶する事により Fp 190〜191。 となる. 本品と前述し た (V) とを混融しても融點降下を示さない.

試料 $\left(100^{\circ}, 6\right.$ 時間㑯空乾燥) $3.085 \mathrm{mg}: \mathrm{CO}_{2} 8.215 \mathrm{mg}, \mathrm{H}_{2} \mathrm{O} 2.845 \mathrm{mg} \longrightarrow$ 試料 $3.725 \mathrm{mg}: \mathrm{AgCl}$ $1.160 \mathrm{mg}$.

$$
\begin{array}{rlllllll}
\mathrm{C}_{29} \mathrm{H}_{49} \mathrm{O}_{3} \mathrm{Cl} & \text { 計算值 } & \mathrm{C} & 72.37, & \mathrm{H} & 10.27, & \mathrm{Cl} & 7.37 . \\
& \text { 實驗値 } & \mathrm{C} & 72.62, & \mathrm{H} & 10.32, & \mathrm{Cl} & 7.70 .
\end{array}
$$

脫卧；本品 $0.7 \mathrm{~g}$ に $20 \%$ アルコール性 $\mathrm{KOH} 20 \mathrm{cc}$ を加へ水浴上て 2 時間煮沸後水を加へ， エ 一テルと共に振盪し, ェーテル層を水で洗滌, 乾燥後エーテルを溜去し, 残渣を醋酸エステルから再結晶 して Fp 141〜141.5 の鱗片狀晶を得た。 $\alpha$-Cholesterin-oxyd (Fp 141.5〜142º) と混融しても毫も融點胮 下を起さない，諸性䓄亦よく一致する.

(V) $\leftrightarrows(V I)$ の吟味 前述の (VI) $0.3 \mathrm{~g}$ をクロロホルム $30 \mathrm{cc} に$ 溶解し́, 水冷しつつ畭燥監酸瓦斯 さ3 時間導入後 1 夜放置し, 然る後既述したやらに處理して,アルコールから得られる結晶は Fp 198〜200 を示し (V) の生成は認められなかつた。

次に (VI) $0.2 \mathrm{~g}$ をクロロホルム $20 \mathrm{cc}$ に溶解し, 水浴上に沸騰させながら乾燥籃酸瓦斯を 1.5 時間導 入後前述の如く處理したが，アルコールから析出する結晶は初めから Fp 1960・を示し（V) への轉位は認 
められなかつた.

更に（V) に就ても同樣の反應を行つたろ゙此の場合にも只原料を包收したに止まる.

Cholestan-triol (II) に覺酸瓦斯一メタノールの作用

A) 3-Acetoxy-5-oxy-6-chlor-cholestan（V) の生成 前報に記載した 3.6-Diacetoxy-5-oxy-

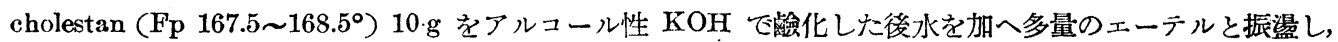

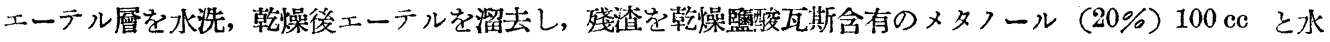
浴上で 2 時間著沸する. 然る後多量の水を加へてェーテルと振湯しエーテル層を稀 $\mathrm{NaOH}$, 水厄洗临, 乾 燥後エーテルを溜去し, 殘渣を無水醋酸と竟沸してアセチル化を行ふ。其の後常法に從つて處理した後ア ルコールから再結晶して Fp 190〜191の細針狀晶を得た。本品と前述した（V) とを混颜してす融點降下 は起らない Liebermann 反應も全く同樣である.

B) 3.6-Diacetoxy-5-chlor-cholestan ((III) の Diacetat) の分離 上述の (V) を除去した アルコール母液を濃縮して 後放置すれば針狀晶が析出する，之を更にアルコールから3 他再結晶して Fp 112〜113․の太い針狀晶を得た。

試料 ( $\left(80^{\circ}, 6\right.$ 時間萁空乾燥) $4.035 \mathrm{mg}: \mathrm{CO}_{2} 10.530 \mathrm{mg}, \mathrm{H}_{2} \mathrm{O} 3.540 \mathrm{mg}$ - 試料 $5.450 \mathrm{mg} ： \mathrm{AgCl}$ $1.490 \mathrm{mg}$.

$$
\begin{array}{rlllllll}
\mathrm{C}_{31} \mathrm{H}_{51} \mathrm{O}_{4} \mathrm{Cl} & \text { 計算值 } & \mathrm{C} & 71.15 & \mathrm{H} & 9.83 & \mathrm{Cl} & 6.78 . \\
& \text { 實驗值 } & \mathrm{C} & 71.17 & \mathrm{H} & 9.82 & \mathrm{Cl} & 6.76 .
\end{array}
$$

試料 $0.0210 \mathrm{~g}$ をクロロホルム 3 ce 汇溶かし $2 \mathrm{dm}$ 管て觀測; $[x]_{\mathrm{p}}^{170}=-45.0^{\circ}$

本品を後述する純粹な $\beta$-Oxyd 製造する原料に用ひた。

純粹な $\beta$-Cholesterin-oxyd の製造上記 3.6-Diacetoxy 5-chlor-cholestan $5 \mathrm{~g}$ を 10\% アルコー ル性 $\mathrm{KOH} 150 \mathrm{cc}$ と共に 2 時間水浴上に煮沸後水を加へ, 多量のエーテルと振蕰し, エーテル層を水洗, 乾洜後エーテルを溜去し殘渣をメタフールから再結晶して $136^{\circ}$ で不銳敏に熔融する針狀晶を得た. Lie-

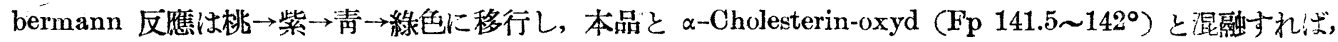
$102^{\circ}$ 厄熔融し始め $125^{\circ}$ て澄明に愹融する。

試料 $\left(100^{\circ}, 6\right.$ 時聞自空乾燥) $3.465 \mathrm{mg}: \mathrm{CO}_{2} 10.210 \mathrm{mg}, \mathrm{H}_{2} \mathrm{O} 3.540 \mathrm{mg}$.

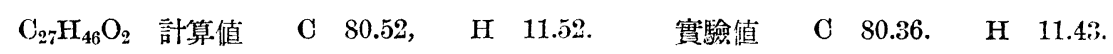

圾料 $0.0202 \mathrm{~g}$ をクロロホルム $3 \mathrm{cc}$ に溶し $2 \mathrm{dm}$ 管て觀測; $[\alpha]_{1 j}^{170}=+10.4^{\circ}$.

アセチル化；上記物質を無水醋酸と著沸後常法に從つて處理し，メタフールから Fp 100〜101の鱗 片狀晶を得た。メタフールで再結晶を繰り返しても之以上融點は上昇しないが，アセトンから再結晶する と Fp 112 1130 の板狀晶となる. 本品と $\alpha$-Cholesterin-acetat-oxyd (Fp 990，不銳銠）とを湿融すれ代， $85^{\circ}$ で熔融し始め 1120 て澄明となる。本品 $0.0200 \mathrm{~g}$ をクロロホルム $3 \mathrm{cc}$ に溶解し $2 \mathrm{dm}$ 管て觀測した が旋光度は \pm 0 であうた。

試料 $\left(80^{\circ}, 6\right.$ 時間傎空乾燥) $3.975 \mathrm{mg}: \mathrm{CO}_{2} 11.445 \mathrm{mg}, \mathrm{H}_{2} \mathrm{O} 3.900 \mathrm{mg}$.

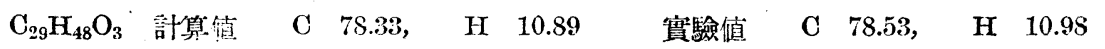

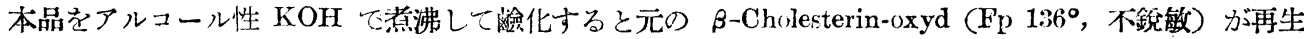
ずる.

\section{純粹な $\beta$-Cholesterin-acetat-oxyd の開裂に就て}

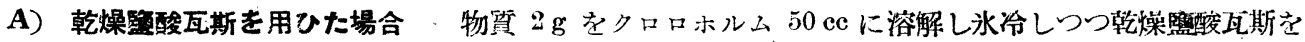
1.5 時間導入して後既述した如く處理してメタノールから Fp 19S〜200の鱗片狀晶を得た. 本品と前述 
した 3-Acetoxy-5-chlor-6-oxy-cholestan とを混融しても融點降下は起らない。

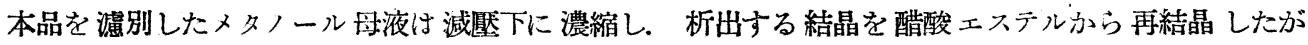

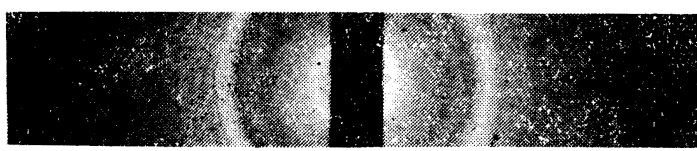

第 1 圖

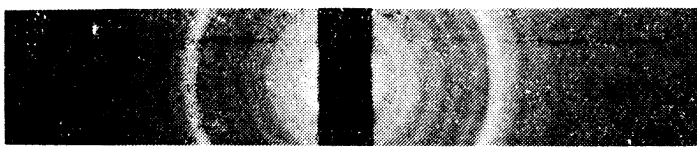

第 2 圖

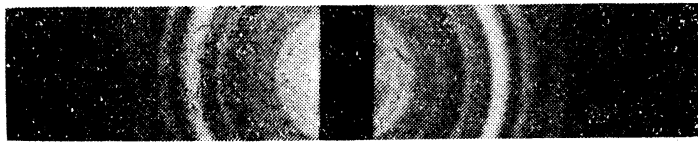

第 3 圖

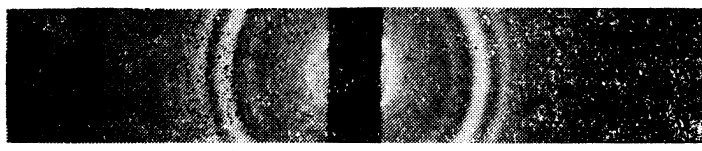

Fp 198〜200 の鱗片狀晶を得た のみであつた. 更に (V) の副成

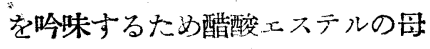
液を減區下に溜去し, 殘渣さエー テルに溶解し, 采洗, 乾燥後エー テルを溜去する・此處に得た残椬 を無水醋酸と墓沸してアセチル化 して後常法に從つて處理して, メ タフールから Fp 112〜113ㅇ太 い針狀晶壳得心. 本品と 3.6-Di一 acetoxy-5-chlor-cholestan とを混 融しても融點降下を示さない. (V)の副生は認められなかつた。

B）涾醋酸を用ひた場合 ·物 質 $1 \mathrm{~g}$ を氷醋酸 $20 \mathrm{ce}$ と共に石 綿板上て 1.5 時間煮沸後多量の水 を加へて析出する結晶を㥁別し, 之をエーテルに溶解する・エーテル層を稀 $\mathrm{NaOH}$, 水て洗涤, 乾燥後エ ーテルを溜去すると油狀物質が残留する，之を無水醋酸と煮沸後常法に從つて處理した後エーテル残渣を メタフールから再結晶して Fp 148.5〜150 の針狀晶を得た. 本品と既知の 3,5,6-Triacetoxy-cholestan と 混融しても毫も融點降下を示さない.

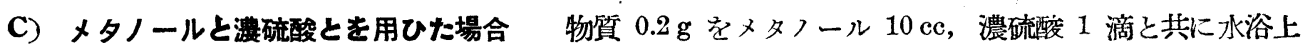
に 1.5 時聞劣沸して後前報1)に記載した如く處理して Fp 203〜204 の鱗片狀晶を得た. 3,6-Dioxy-5一 methoxy-cholestan と潉融しても融點降下を起さない.

\title{
$\mathbf{X}$ 線粉末弿上圖參照
}

\section{蒲黃ステリンのクロム酸酸化に就て}

\author{
服部順五 中村勝太郎 \\ 株式會社武田長兵衞商店研究部（昭和 15 年 5 月 2 日受理）
}

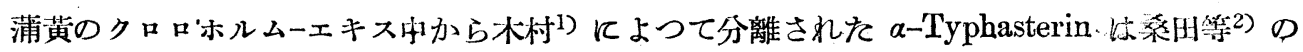
研究によると高等植物に廣く分布する Sitosterin, $\mathrm{C}_{29} \mathrm{H}_{50} \mathrm{O}$ ， と同一物質ですると云ふ。著者等

1) 本誌 50,843 [昭 5]. 2) 本誌 57, 246 [昭 12]. 